\title{
PREFACE TO THE SPECIAL SYMPOSIUM IN HONOUR OF PROFESSOR OTTO TRIFFTERER'S 80TH BIRTHDAY
}

When I had the pleasure to attend the Symposium which the Faculty of Law of the University of Salzburg organized in honor of Professor Triffterer on the occasion of his 80th birthday on 18 March of this year, it came immediately to my mind that this special event for this special person deserves a wider audience and I agreed with Bill Schabas soon afterwards that we should dedicate a Special Symposium of Criminal Law Forum to fulfill that purpose. I am glad that my co-Executive Editor Carsten Stahn also agreed to our plan and that Joe Powderly quickly and efficiently assumed his responsibility as Managing Editor.

What we now present to the worldwide readership of the Forum are not only the four speeches delivered at the Salzburg Symposium by Triffterer's longstanding friends and colleagues Roger Clark, Judge Anita Ušacka, Bill Schabas and Judge Daniel Nsereko but also two further texts. First and starting off this Special Symposium is a very personal biographical note by Triffterer's pupil and colleague in Salzburg, Kurt Schmoller, complemented by an account of Triffterer's coordination of the Salzburg Summer School of International Criminal Law by Astrid Reisinger-Coracini. Secondly, an original paper by Otto Triffterer himself commenting on and analyzing some of the issues treated in the four speeches.

There is not much that an outsider like myself can add to the biographical note presented by Schmoller and Reisinger-Coracini. I can only say, as a scholar of international criminal law and an admirer of Otto Triffterer's energy and influence in the field, that it fills me with great pride and satisfaction that we have taken the decision to dedicate this Special Symposium to Otto Triffterer. For those of us working in the field it is by no means an overstatement to

\footnotetext{
* Professor of Criminal Law, Criminal Procedure, Comparative Law and International Criminal Law at the Georg-August Universität Göttingen; Judge at the District Court (Landgericht) Göttingen; Executive Editor, Criminal Law Forum.
} 
point out that Triffterer and his Salzburg team have produced the "bible" on the ICC Statute. "The Triffterer" set a standard that is yet to be met by other works in the field. While it is well known that practioners have little or no time to read legal texts not directly relevant to their cases or proceedings, nobody at the International Criminal Court, from the intern right up to the judges, can afford to ignore what has been said in "the Triffterer". Thus, there is already a Triffterer legacy which hopefully will be continued by younger scholars. It is our honest hope that this issue will contribute to this legacy.

Göttingen, October 2011 